\title{
3. Constraints on researchers acting as change agents
}

\section{Sarah Holcombe}

This chapter reflects on the role of research and the constraints on researchers acting as change agents in the context of a project on an Aboriginal governance issue. By examining what has happened to the knowledge produced in the context of this project, with the Anmatjere Community Government Council (ACGC) about a fringe camp within the Ti Tree township in the Northern Territory (NT), the tensions between advocacy and impartiality are explored. This fringe camp is without any basic servicing, although there has been a permanent Aboriginal population there since settlement of the town from the late 1880s. The conundrum raised by this research project was that although we found pathways to change, our suggestions were not pursued either by the ACGC or the NT Government. Considering why this was the case leads to an examination of power relationships between Aboriginal people and the state, as mediated through the council, and an exploration of the impacts of policy in this context. Thus, the challenges of operating as a researcher within this environment suggest that the impact of research is constrained by the limits to collaboration, both by the means through which policy becomes a rationalising tool of the NT Government and the deeper local history of colonialism.

\section{Background}

The Ti Tree fringe camp came to the attention of the then Minister for Central Australia, Peter Toyne, who wrote to the ACGC in 2002 expressing concern about the lack of servicing and encouraging the council to do something about it. By any standards, the living conditions there are not ideal. Will Sanders and I were requested by the council to assist them in developing a strategy through which they could then respond to the NT Government. Thus, the impetus for the research into the Creek Camp issue was not initiated by the ACGC, but was prompted externally, and we happened to be available to undertake it.

In three reports to the ACGC, produced over a period of a year and a half, we documented the history, mobility patterns and aspirations of the Creek Camp residents, as well as canvassing other Ti Tree residents' perspectives of the place and the possibilities for NT Government action. However, a year and a half since the last of these three reports was delivered there has not been any significant change in the conditions of the place for its residents. Was our work 'rendered invisible' at 'the official and political level?' (Sutton 2001: 142). And how does this official and political level intersect with the level at which the Aboriginal 
people in this story are operating? Indeed, examining the intersection of our research with these two layers or sites of governance draws out the tensions between them. The contention is that the Aboriginal silence or ambivalence on the issue is, partly, a symptom of powerlessness; silence as 'passive condition' (cf. Rose 2001: 92) as the violent history of the pastoral frontier is recalled. More recently, this history of marginality is reinforced by NT Government policy, as the policy at issue was found to be underpinning the current status quo of Creek Camp. Examining how this policy became manifest as a government rationality was revealed as the research sought out possibilities for change, and in the process realised that these were limited by the policy. This NT Government policy was to the effect that no further Aboriginal urban living areas were to be established within townships.

By examining what has happened to the knowledge produced in the context of the Creek Camp research, the tensions between advocacy, development and research leading to change can be explored. At the risk of sounding 'postmodern', this reflexive gaze can also begin to unpack my own expectations about the outcomes of the research process, in an attempt to consider my own positionality as an anthropologist. The debate between Sutton (2005) and Cowlishaw (2003) on the role of anthropology in policy making and public debate highlights a number of the tensions in the discipline, which are brought to the fore as one engages with the diverse non-Aboriginal ideologically driven interests in the field. Although I do not view 'anthropology ... primarily as a wing or instrument of political activism' (Sutton 2005: 40), as Sutton has suggested Cowlishaw does, it seems to me that solid anthropological research can and should influence policy. The challenge is facilitating and enabling this uptake, as an integral element in the research process. To this end, this research also benefited from an interdisciplinary approach, with Will Sanders as political scientist teaming with myself, as social anthropologist. The different approaches to knowledge construction that both disciplines brought to the enterprise have been valuable for the research and will be considered below.

A reflexive examination of the research method is a key to interrogating knowledge construction. In the case of this project this included realising the value of longitudinal research and relationship building with the research hosts. In our case, as mentioned above, the research hosts and collaborators were the ACGC. ${ }^{1}$ And, as will be discussed, each stage of the research into the Creek Camp issue and its potential development was a test of this relationship. It was

\footnotetext{
1 The ACGC was established in 1993. It incorporated a region that could be broadly understood as Anmatyerr (language group) country; hence the council's name (though note the different and orthographically incorrect spelling of Anmatjere). This council was the first-and remained the only-regional council in desert NT. It incorporated 10 settlements structured on a ward system, incorporating a population of 1,400 predominantly Aboriginal people, and covering a region of 3,631 km 2 . See Sanders this volume, Chapter 11.
} 
not to be taken for granted; after all, we as researchers presented ourselves to the council as having something to offer. Thus, we had to show that what we were offering was of some value. Unpacking how this research engagement was negotiated offers a window into the governance of research, as much as the governance processes within this all-Aboriginal council and their engagement with the NT Government over the Creek Camp issue.

When we approached the ACGC in 2004 to ascertain their interest in having us, as researchers, working with them on governance issues, it coincided with the arrival of a new Chief Executive Officer (CEO), who was about to begin a three year tenure. This fortunate timing meant that he was open to our involvement and not at all protective about sharing his new understandings of the current council situation. Ironically, although his initial and ongoing support was in many ways crucial to the development of our research project, his conservative perspective concerning the maintenance of the status quo of the Creek Camp could also, arguably, be perceived as constraining the uptake of the research findings. Yet, as will be examined, the role of the CEO in relation to this issue was only one element in a complex multi-sited government rationality (a concept borrowed from Foucault, discussed below).

As I will elucidate, the value of long term research in one place, allowing ongoing reflection on the research, also enables exploration of the ways in which policy unfolds as truth and tends to reaffirm the status quo. Thus, as this paper revisits the Creek Camp issue, it can continue to explore the dynamics of NT Government agency in terms of a governmental rationality and the ways in which this plays out in policy practice. In my attempt to answer the question "what is "policy" and where is it located?' I have drawn inspiration from Foucault's (1991) concept of 'governmentality' (or government rationality) and more latterly Rose's (1999) interrogation of this concept. My perhaps simplistic reading of the governmentality concept understands it as a concern with the practices of governing, rather than the structures or institutions of government. How these practices gain legitimation and become mobilised, as they define the parameters of possible conduct and how the truths about these parameters are developed and circulated as discourse, drive a governmentality approach. In this reading, policy is understood as a core device or instrument of the governing rationality. Realising the intimate relationship between knowledge construction and power also permeates this approach to interrogating the governing process.

I suggest in this chapter that if we, as researchers, cannot change the status quo we can at least expose the opaque structural relations of power and the historical legacies that express themselves among the Aboriginal councillors in their ambivalence and division over the future of the Creek Camp. However, before discussing this issue, I will briefly overview the research findings. 


\section{Making the concept of governance tangible}

The concept of 'governance' is multi-dimensional as it moves between layers of institutions, governments, localities and discourses. To give this concept meaning to the ACGC, and to the then CEO, we took what we called an 'issues' based approach. This approach led us to Creek Camp, as its existence was an 'issue' for the NT Government that required a response from the council. Assisting the ACGC to develop a response to the Creek Camp 'issue' evolved as each period of research and subsequent reporting back opened up further avenues of investigation. The research could be understood as structured by three principal periods of activity. To help make the governance concept real for people, we delivered, verbally and via reports, the findings of each period of research activity in plain English to the council. We ensured that our subsequent visits coincided with a monthly council meeting, where our reports were an item on the agenda. The aim was that this would enable informed discussion about the Creek Camp and canvas potential options for change.

Our first report to the ACGC (June 2005, see Holcombe and Sanders 2007b) ${ }^{2}$ provided an overall snapshot of the residential arrangements of Creek Campers in what could be described as a 'survey'. Using both a questionnaire and open ended interviews we ascertained length of residence, camp composition, mobility patterns, the attractions and difficulties of living at Creek Camp, and people's preferred future residence and aspirations. We estimated 102 current and recent residents of the camp, grouped roughly into 13 sub-camps of self-identified Anmatyerr and Warlpiri people. The aspect of these findings that was perhaps the most informative for the Aboriginal councillors was the residential and development aspirations of the Creek Camp residents. Ten of the 13 camps indicated that they sought to remain in Creek Camp in the future and that they would like a minimum of reticulated water and ablution blocks. There was, however, some difference of opinion over the issue of housing. This considerable interest in development of some sort by all Creek Camp residents (whether or not they sought to remain there into the future) led the ACGC to ask us to continue on the project by broadening our enquiry beyond the Creek Camp.

The second stage of the research entailed a survey of residents of the roughly 35 houses in the Ti Tree town, and discussions by one of us (Sanders) with senior NT Government officials about their understandings of development possibilities of Creek Camp. As will be discussed, our key government contacts had, until then, been officers in the NT Department of Local Government. In the survey of Ti Tree town residents, other than ascertaining some basic demographic and social characteristics, we specifically asked their perspectives about the potential development of the Creek Camp. Of the 16 people interviewed, only three were

\footnotetext{
2 The three separately dated reports to the ACGC have since been compiled as a single document in Holcombe and Sanders 2007b.
} 
opposed to any development there. The significant majority were supportive of development of the Creek Camp, including buildings, if that was what people wanted. The perspectives offered by those NT Government officials involved in infrastructure provision, however, had a somewhat different focus. They indicated that Creek Camp's position on 'unallocated vacant Crown land' meant that there was no standard government mechanism through which it could be provided with reticulated services, and that for such servicing to happen an organisation, such as the ACGC, would have to apply for and obtain 'appropriate' title or tenure over the land. They would then also need to find a source of funding for the services. Given these apparent difficulties, the focus of most of the NT Government officials we spoke with was, rather, on ways in which Creek Camp residents could be encouraged to move elsewhere. ${ }^{3}$ Finally, we noted in our second report (May 2006) that there seemed to be some basis of support for doing something in Creek Camp among ACGC members, as well as among Creek Camp residents and Ti Tree residents more generally. However, it was clear, as we reported back, that the response from the Department of Planning and Infrastructure (DPI) within the NT Government had not been positive.

The third and final report to the ACGC (July 2006) was brief, as it outlined a new possibility for the development of Creek Camp that emerged as the second report was being circulated to NT Government officials. This possibility (originating from officials in the DPI) suggested that certain basic reticulated services such as water and electricity could possibly be provided under licence or 'permissive occupancy', without the legal complexity of land tenure change. The advantages of such an arrangement were outlined and included a more straightforward way of ensuring that native title was not extinguished, protection of the assets of the organisation providing the services, and the fact that there would have to be a limit on the services provided. In some ways, this final point suited the caution that Creek Camp residents felt about the possibility of the place becoming like a 'town camp'; the perception that with development, greater numbers of people may be attracted, with the associated risk of the place becoming a 'drinkers camp' and thus changing the quiet, spread out nature of the place, one of its key advantages. Nevertheless, although this possibility of a more amenable legal option sounded hopeful and was discussed in our presentation to the council, the issue of whether this path was amenable as a policy option was less certain.

\footnotetext{
${ }^{3}$ One of the most frequently identified options for relocating people was the planned development of aged care housing in the Ti Tree town. This was discussed as an extension of the Aged Care Centre that currently delivered other services, such as food, clothes washing and ablution facilities, to many of the elderly core residents of the camp. However, the funding arrangements for this facility seemed far from settled and, likewise, discussions with potentially affected Creek Camp residents. Our preliminary discussions with aged care staff and the Creek Camp residents who relied on the services suggested that even if funding were forthcoming, such a significant shift in living arrangements may not be welcome to many of them.
} 
Making governance tangible in this research developed as a concern with revealing the legal and (later) policy structures that had the potential to facilitate or hinder change, as much as opening a space for dialogue about the potentials for change. ${ }^{4}$

\section{Research funding as a determinant of methodology}

This research, like much research, was (and is) driven by engagement with a broader agenda and set of partners. As part of both an Australian Research Council Linkage Project (the ICGP between CAEPR and Reconciliation Australia, with the financial support of the Western Australian, NT and Federal Governments) and a Desert Knowledge Cooperative Research Centre (DKCRC) project (with 28 research partners), it is compulsory to cultivate relationships with these partners. As such, it is not ivory tower research as it aims to 'make research count on the ground' (Smith 2005: 5) in its applied approach. To do this, as researchers we have a responsibility to engage with government officials and non-government organisations, to both ensure the project is relevant and to disseminate the research findings. There is also a responsibility to work collaboratively with Aboriginal people with whom the research is being conducted. Indeed, through the DKCRC we received monies for collaboration in the field, which I will discuss further below. The Anmatyerr region, with the ACGC as its centre, is developing as something of a research hub for the DKCRC, with several other research projects underway, including desert or outback livelihoods and bush foods projects.

In our project, we discussed the research findings at length with officials in the local government department and in more restricted fashion with other departments, and with the Central Land Council (CLC). ${ }^{5}$ After, and sometimes before, each period of field research we held an 'exit interview', which served to brief the attending officers on the major findings of our period of research. In some ways, we were able to offer informed critique of policy implementation 'on the ground' and also offer informed perspective about Creek Camp and associated issues, such as housing supply in the Ti Tree town. Those participating in the local government department discussions tended to be the Community Development Officer for the region and the Regional Manager for Central Australia. Those in the CLC discussions were usually a policy officer and the

\footnotetext{
${ }^{4}$ It is also important to note that although there were three broad stages of the research that sought to canvas different perspectives about the Creek Camp issue, we returned to Ti Tree, and specifically Creek Camp, on at least six other occasions during this time. Each time we were able to gain a greater understanding of the dynamics of the Creek Camp population and the NT Government understandings of the place. We continued to feed this information back to the ACGC and it was also summarised in the reports. Additionally, we spoke separately with many of the councillors about the issue during these visits. In this way, Creek Camp remained an active issue.

5 The CLC is a representative statutory body under the Aboriginal Land Rights (Northern Territory) Act 1976 (Cth) (ALRA). It acts as an advocacy organisation for Aboriginal people in relation to land rights, including native title rights, land management and development, and so on.
} 
regional anthropologist. These conversations were of course multi-directional, as we were also returning to our core audience - the ACGC and Creek Camp residents — with updates from these parties.

The collaborative aspect of the research with the ACGC and the Creek Camp residents evolved in a number of ways. Firstly, as we did not arrive with a ready made research topic, the development of the research agenda was itself collaborative. Although it would not be entirely correct to suggest that it was an Aboriginal driven research agenda, ${ }^{6}$ given that it was initiated by the NT Government, it was nevertheless a topic of considerable interest to both the Aboriginal councillors and the Aboriginal residents of Creek Camp and Ti Tree. Furthermore, the broadening of the research to include the Ti Tree residents and official possibilities for change was driven by Aboriginal interests.

As neither Sanders, nor myself, spoke Anmatyerr or Warlpiri and neither of us had experience working in that region, ${ }^{7}$ we engaged an Anmatyerr and Warlpiri speaker to act as both interpreter and research facilitator. We approached the ACGC for suggestions and a male councillor who lived at the nearby settlement of Pmara Jutunta, and who had training as an interpreter, was appointed. He was paid an agreed rate that equated to the council sitting fees and we bought him lunch each day. ${ }^{8}$ One of the challenges in undertaking research with a population that lives outdoors is that there are no doors to knock on. Having a local Aboriginal person introduce us to residents of the various camps was crucial in assisting us to navigate the spatial etiquette that defined the domestic arrangements. When our first 'research facilitator' was unavailable, as happened on our third trip, we were able to engage another female councillor from the same settlement. It was also decided by the ACGC that each interviewee of the Creek Camp should be paid $\$ 20$ for each questionnaire. We continued this practice in our follow-up questionaries, as it was 'work for the council'. When our research broadened to include residents of the town, however, it was not appropriate to engage Aboriginal research facilitation. Nor did we pay the significant majority of these interviewees.

\footnotetext{
6 See for instance the CRC for Aboriginal Health (<http//:www.crcah.org.au $>$ ) for examples of an Aboriginal driven research agenda.

7 I had worked as a regional anthropologist for the CLC. However, this work was undertaken many years ago (from 1990-94) and very little of it was spent in this particular region. In fact, the Anmatyerr region had been part of a 'break-away land council' movement and as such there had been relatively little CLC engagement there since the successful land claim over the Ti Tree pastoral lease in 1986 (see Aboriginal Land Commissioner 1987; see also Morton 1994). This has changed more recently, with an active CLC presence in the region.

${ }^{8} \mathrm{He}$ also attended a DKCRC workshop in Alice Springs with Sanders and myself, as the first stage of the research was also part of its early 'Governance, management and leadership' theme. The workshop was an update on progress and future directions for the various DKCRC sponsored research projects.
} 


\section{Positionality and 'balance'}

As discussed earlier, the nature of the research method was effectively relationship building. We were given a new research task after reporting back from the previous research task at each council meeting. In this way we were being monitored and judgements made as to the ongoing value of the research relationship. This also meant that, perhaps even more than otherwise, we had to be alert to negotiating the diverse interests within and between the ACGC, the township and the NT Government. Within this highly politicised context of research, ensuring that the 'facts spoke for themselves' was crucial. The three reports to the council were exactly that: 'reportage'. They were factual and evidence based with very little interpretive analysis. We were careful to avoid alienating any of our research constituency.

For instance, within the all-Aboriginal ACGC there was a range of views about the Creek Camp. There were councillors who were also Creek Camp residents, one of whom sought only basic reticulated services in the camp-not housing - while the other sought a house within the township. The diverse population profile of the Creek Camp also suggested the need for us to observe a cautious approach. As the majority of the residents were highly mobile - many were regular part time residents from Nturiya, $17 \mathrm{~km}$ to the west, while other 'residents' were long term visitors from Warlpiri settlements further to the northwest - there was concern that development of the place might make it more attractive for these visitors and change the camp's quiet environment. Thus, there were not only different views about the extent of development that should occur, but there was also a view among some within the council that only those people who worked should be given access to a house.

An approach driven by a straightforward advocacy for equality in mainstream housing and servicing was not appropriate in this context. Nevertheless, balancing an approach that advocates a 'human rights' agenda, which speaks of the rights to basic services, such as running water and sturdy shelter, with the multiple Aboriginal agendas and the agendas of government, has been an especially challenging aspect of the research. Attempts to try to 'get to the bottom' of why the all-Aboriginal council has not brought greater pressure to bear on the NT Government for even minimum servicing of the camp has uncovered not only the multiple views (some of which are canvassed above), but a guarded and uneasy history with their potential advocacy body (the CLC) and a deeper history of a violent colonial frontier. ${ }^{9}$ A daily reminder of this 'frontier' is the apparently entrenched 'moral geography' of the Ti Tree township (Rowse 1998: 9), with the Stuart Highway acting as the divide between the camp

\footnotetext{
9 Possibly the worst massacre in Central Australian settler history occurred at neighbouring Coniston Station in 1928, where between 30 to 100 Warlpiri and Anmatyerr men, women and children were murdered in reprisal for the murder of a non-Aboriginal dingo scalper (see Cribben 1984).
} 
and the more formal residential dwellings. The Ti Tree town is the centralised focus of services within ready reach of the non-Aboriginal population contrasting with the surrounding dispersed Aboriginal population, which is without clinics, schools, or stores. This has been discussed at length elsewhere in terms of the regional colonial history and the subsequent spatialising of social relations (see Holcombe and Sanders 2007a) as Ti Tree became an enclave for settler interests surrounded by Aboriginal land. The point to reiterate here is the consequent embeddedness of this structure of Ti Tree as the centralised service centre and the gradual depletion of resources from the neighbouring settlements from whence many of the part-time Creek Camp residents have come. ${ }^{10}$

Arriving at this research balance of local historical depth, ethnographic insight and the intersections with NT bureaucratic agency has only been possible with an inter-disciplinary approach to the 'Creek Camp issue'. Sanders' method of dealing with the bureaucrats and the ACGC CEO has been to strategically uncover the options for development and then lay out the impediments to this development from within the same structures in a clinical objectivist approach that leaves little room for subjective dismissal (see especially Sanders and Holcombe 2007: 80-2, 84-6). My anthropological approach has been to interrogate the evolution of power relations between the Aboriginal people and the NT Government, and identify both impediments to and spaces for Aboriginal agency in an attempt to grapple with the cultural dimensions of choice in the 'Creek Camp issue'. To achieve this we combined quantitative and qualitative approaches in our discussions with people. Whilst I found it constraining to remain within the bounds of a questionnaire, such standardisation was essential in ensuring a comparative and systematic approach to data generation. It was equally important, however, to range beyond the questionnaires to ensure that the local contexts were grounded in an understanding of genealogical connections between Creek Camp residents, their customary attachments and other biographical details, to paint a fuller picture.

\section{The role and power of 'officials'}

In thinking about the governmental structures that acted as nodes in a network of potential change agents, several officials stand out in this research. It has been noted elsewhere that 'the response to altering the status quo [of Creek Camp] has been limited along all links of the decision making chain' (Holcombe and Sanders 2007a: 345). Here I would like to give further consideration to the make-up of this chain. As a multi-sited chain, its links are mobilised across NT Government departments and are at once hierarchical ('change must come from the top') and horizontal in the shared nature of the policy discourse and its emergence as a rationality. Without focusing unduly on the role of any one

\footnotetext{
${ }^{10}$ For instance, the stores closed at nearby Nturiya and Pmara Jutunta in 2002 and 2005 respectively.
} 
official, it seems to me that a policy language developed, which ensured that those officials 'on the front line' spoke in concert. Once this language emerged, there was little shifting it, and the line between what was apparently legally possible and what was policy seemed to become blurred. The officers that emerged in this research at this front line were the ACGC CEO, officers in the local government department and officers in the DPI.

Having finished his contract, the ACGC CEO who began his three year tenure as our research project was beginning has now left. Our research relationship, however, has continued with the council. An integral element of the project is that we ensure that our field research coincides with the monthly council meeting, although it may be every third or fourth meeting that we can attend. However, there had been little or no mention of the Creek Camp issue since we tabled our third and final report to the ACGC in July 2006, although we had suggested a number of ideas for 'action' or 'consideration' from this and previous reports. One idea that developed from our discussions with councillors about the third report was to invite an officer from the DPI to attend an ACGC meeting and discuss the options and issues about potential development with councillors, and the council moved a motion to do so. We then took a back seat and observed that over the next nine months no officer from the DPI attended a council meeting. It is unclear whether this was because of reluctance on the part of the DPI or a lack of pushing on the part of the CEO.

Interestingly, the issue of Creek Camp was back on the agenda as an item at the first ACGC meeting that Sanders and I attended with the new CEO in June 2007. One councillor, who is also a Creek Camp resident, stated that 'he would like to see power and water connected to Creek Camp' (ACGC Council minutes, June 2007). This of course was not the first time he had said this, but as noted above, it had not been raised for some time. During our earlier interviews with him, he had made it clear that he sought these essentials, while the issue of housing was not his uppermost priority. However, he had never made so plain a request at any previous council meetings that we had attended.

It is apparent that the issue had lain dormant after our reports had been tabled and that this was not entirely at the discretion of the councillors. Nevertheless, it is pertinent to recall that the ACGC is itself divided and ambivalent as to future development possibilities or options for change at the Creek Camp, and this had not changed over the course of the research. That the new CEO seems to have a slightly different approach to the issue emerged at the same council meeting. She requested an update about possible courses of further action from us and was open to the possibility of formally requesting the attendance of an officer of the DPI to discuss the issue at the following meeting. Time will tell whether a DPI officer attends. 
Officers in the DPI report to a different minister than do those in the Department of Local Government. ${ }^{11}$ However, as officers in the DPI were the ones who initially identified the legal and financial obstacles to reticulated service at Creek Camp and then the more ready possibilities, as noted earlier, it would seem that they are pivotal in the process of potential change. When the potential for development under licence or permissive occupancy was reported back as a possible option for Creek Camp in a government forum ${ }^{12}$ at which Sanders presented, he was informed by another DPI officer that in fact it was not necessarily an option. As was noted elsewhere (see Sanders and Holcombe 2007: 85), this was because of a NT Government policy relating to the establishment of any new Aboriginal 'community living areas', particularly in towns. This policy shift away from Aboriginal urban living areas, which began in the 1980s, has been brought to prominence recently in relation to 'town camps' as 'reverse apartheid' by the then Federal Minister for Indigenous Affairs, Mal Brough. ${ }^{13}$ He raised, as a public issue, the sub-standard living conditions of the 19 town camps in Alice Springs. This policy position, away from the establishment of town camps, is primarily evidenced by the lack of structured government support for them, rather than a publicly declared position. Nevertheless, this somewhat opaque policy cannot so readily explain the historical legacy of government inaction over the Creek Camp.

The role that other officials play (such as those in the Department of Local Government) in this chain of rationality is also relevant. When the issue was raised again by the same councillor/Creek Camp resident at the 2007 May ACGC meeting (with the new CEO), the official noted that 'due to the fact that Creek Camp was situated on Crown Land [NT] Power and Water Authority would not provide pipes or services to Crown Land due to legal ramifications'. As examined in some detail above, the position detailed by this officer was indeed underwritten by a policy agenda, as much as legal constraints. Yet, the opacity of the policy position suggests that locating it is indeed a challenge, which may explain why the policy position about town camps was not outlined in this public forum.

It seems that the 'policy' evolved as a shared understanding amongst public service officers, a number of whom were long serving. This front line rationality was effective and presented as an insurmountable hurdle. Yet, we could not

\footnotetext{
11 The former Minister manages the portfolios of Planning and Lands, and Infrastructure and Transport. The latter Minister, to which the Department of Local Government answers, manages the Local Government and Housing portfolios and 'assists' the Chief Minister with Indigenous Affairs. So, it would seem that the boundaries between ministerial responsibilities in relation to the Creek Camp issue are somewhat blurred.

12 The 'Southern Regional Executive Coordination Committee', which meets monthly and has senior representation from the various government departments and statutory agencies.

13 OneNews (New Zealand), 'Aborigines reject land deal', 24 May 2007, <http://tvnews.co.nz/view/ page/1148892> [accessed 29 May 2007].
} 
locate any written policy to the effect that leases were no longer being offered for Aboriginal urban living areas within townships. The constraint offered by this policy was able to dominate the discussions and set the parameters of possibilities. As a governmentality, it became authoritative through its common useage. For Foucault, the very activity of governing is conditional on the availability of a certain notion of rationality, which, in order to be operable, needs to be credible to the governed as well as the governing (see Gordon 1991: 48). The credibility of the policy at issue here emerged in the broader milieu of NT Government politics and its intersections with the Federal Government's recent targeting of 'town camps', as discussed above.

Nevertheless, this policy hurdle was really only one element - albeit a key one - in a confluence of factors that include, as mentioned above, a council with diverse views. Another strategic factor is the under resourced CLC who, if they were to push the issue, would be required to take instruction from Traditional Owners (under s. 23 of the ALRA). Preliminary enquiries suggest that at least some Traditional Owners' interests were not found to lie with the interests of Creek Camp residents. Likewise, post the Native Title Act 1993 (Cth), the development of any new Aboriginal urban living area requires negotiation of an Indigenous Land Use Agreement, which would include a Crown lease for a living area. Again, the CLC would be a key party to such negotiations, as indeed has occurred in other townships. Furthermore, the fact that the township is surrounded by Aboriginal land (Ahakeye Land Trust), where outstation housing currently lies empty for much of the year, had been noted by the previous CEO. ${ }^{14}$

It is apparent, nevertheless, that patience in awaiting opportunities may be an Aboriginal political strategy. Is patience perhaps a form of resistance, a weapon of the weak? Or is this an optimistic way of interpreting passivity in the face of a greater political power? Certainly, a commonly heard phrase is that non-Aboriginal people 'blow in with the west wind and out with the east wind'. Therefore, seizing opportunities to pursue a pre-existing issue of import with a new CEO is standard practice. At any rate, my previous assessment of the lack of action to push for change on the issue as being 'too hard' on the part of councillors (see Holcombe and Sanders 2007a) ${ }^{15}$ seems too encompassing on further reflection. It now seems to me that this earlier analysis perhaps underestimated the power relations within the council and the role that policy plays as a rationalising tool of government.

\footnotetext{
14 The reasons why outstation housing remains unoccupied for much of the year in the ACGC region are numerous. For any individual family, these might include lack of transport and/or high cost of fuel, the death of a relative with whom the outstation is closely associated, and the need to be close to services (e.g. proximity to the clinic, school, store etc.).

15 I noted then that the context of action is 'framed by the colonial history of marginality and violent subversion and a deeper cultural history that values mobility, family obligations and disregards acquisitive materiality' (Holcombe and Sanders 2007a: 346).
} 
As the councillor raised the Creek Camp issue again, I realised that any set of 'findings', and thus analyses, must be bracketed by the research moment. Ultimately, with the re-emergence of the issue by the councillor/Creek Camp resident, it seems to me that if development of the camp is to happen in some form then it is going to have to be driven by a councillor. Persistence by councillors and the active ear of the CEO may yet lead to change.

Geertz (1988: 147) claims that what anthropology should seek to do is 'enlarge the possibility of intelligible discourse between people quite different from one another in interest, outlook, wealth, and power'. The possibility of this has indeed been enlarged by our research project. However, unfortunately, any discourse has been mediated through our reports, verbal and written. As far as I am aware, no non-Aboriginal government or ACGC official has since visited the Creek Camp to discuss any aspects of the research findings or possibilities for change with residents there. ${ }^{16}$ The research, however, did 'debunk' certain preconceptions about the motivations of the residents, so at least the discourse between non-Aboriginal officials about the issue was enlarged by the facts. The analysis clearly demonstrated the diversity of the residents' aspirations, histories, affiliations and reasons for residing in the camp. Several of the myths concerning the place, as a drinking camp and as a camp dominated by itinerant Warlpiri, have also been found to be false. Likewise, the fact that a significant number of the core residents have an attachment to the place under Aboriginal customary law, while the depth of attachment for many others is historically located through many generations of dwelling in the location, seemed crucial in adding weight to the residents' rights.

\section{Enforcing marginalisation: what's in a name?}

A common reference for informal or unrecognised urban Aboriginal living areas is 'fringe camps', while terms such as 'fringe dwellers' and 'town campers' have commonly been used to describe the residents of these types of places. Yet, both these terms for residents carry different connotations. These definitional problems with finding an appropriate term were detailed in a 1982 report by the Commonwealth Parliament's House of Representatives Standing Committee on Aboriginal Affairs (HORSCATAA 1982). As Sanders (1984: 141) noted:

the report recounted in detail both suggested terms and descriptions, and objections raised. [For instance] the term 'fringe dwellers' was criticised, because of its lack of currency among Aboriginal [people] and its frequent use by non-Aboriginals as a term of opprobrium to refer to Aboriginal residents of towns and cities who, in the users' view, should not be there.

\footnotetext{
16 Likewise, I am not aware of the resident Aboriginal councillors holding meetings with other Creek Camp residents about the issue.
} 
The committee eventually decided to use the term 'town campers' because of its less subjective connotations.

These definitional problems are not only indicative of the marginal status of town camping as an Aboriginal urban lifestyle (Sanders ibid.), but it seems that the categorisation of such places as 'camps' is also an attempt to ensure their temporary status by playing into stereotypes of Aboriginal mobility. If these places are labelled as temporary, then it would appear to be the case that the state need not claim responsibility for them. Yet, as we found in the case of the Creek Camp, residential stability emerged as a pattern for a significant number of residents. The implications emerging from this definitional argument could of course equally be applied to the so-called 'town camps' in other towns along the highway, such as Alice Springs, Tennant Creek and Elliot, as they are in fact Aboriginal suburbs. Unlike the Creek Camp, however, these 'town camps' now have some legitimacy as they are on various special purpose leases. Creek Camp is on unallocated Crown land, so the residents are effectively trespassing.

The appellation of 'Creek Camp' to the place at issue in this paper is a non-Aboriginal descriptor, which was not particularly used by Anmatyerr people, although they obviously knew what it referred to. Rather, the place did not seem to be referred to in general terms at all (except in structured contexts of ACGC meetings or this research), but rather was more specifically identified through residences within it, such as 'Old Napurrula's place'. Some older people specifically noted that the Anmatyerr name for the area was Aleyaw (Green et al. 2003: 21). This name refers to a 'sacred site' complex to the south of the council building, which represents two Dreamings that moved through what is now the town. The surrounding Ahakeye Land Trust gets its name from one of them (the bush plum). We were shown this place by two male Creek Camp residents and a councillor who was acting as our research facilitator.

\section{Notions of good development}

If development of the place was on the agenda for the NT Government - which seems extremely unlikely - the issue of equity of access to housing and associated services poses the challenge of what may be appropriate or demand driven servicing, as opposed to servicing on the basis of equity or by mainstream standards. What might be appropriate development? In other words, if the majority of residents were to be granted their wish of a simple tin shed rather than a house, the moral hazard that the Government is barely addressing, and perhaps perpetuating, is the 'third world conditions' under which the residents currently live. However, building mainstream housing for these people, either in the Creek Camp area or in the township, would actively disregard their right to exercise choice. However, this issue of choice is far from straightforward, as has been noted by Cowen and Shenton (1995: 28): 'choice is as much a precondition of development as its result'. Currently, of course, choices for 
change are not being offered. In our discussions with residents we were careful to note that we were not in positions of decision making power.

However, I cannot help but feel frustration, a feeling that is shared by at least one Creek Camp resident, who earlier this year asked us in an agitated manner why we were back again, if our work was not going to lead to a change in their living conditions. So, the likelihood that Old Napurrula may not get her tap and that this research may not lead to active change leads me to quote Durkheim: 'because what we propose to study is above all reality, it does not follow that we should give up the idea of improving $i^{\prime}{ }^{17}$ Hence, the purpose of writing a paper that agitates for an understanding of the constraints imposed on research findings and the contingent possibilities of acting as change agents.

\section{Acknowledgements}

I would like to thank Will Sanders and the diligent editors of this monograph at CAEPR for their guidance, especially Janet Hunt and Stephanie Garling. The Desert Knowledge Cooperative Research Centre (DKCRC) also supported this research through funding for travel and community collaboration.

\section{References}

Aboriginal Land Commissioner 1987. Ti-Tree Station Land Claim, Report No. 24, Report to the Minister for Aboriginal Affairs and the Administrator of the Northern Territory, AGPS, Canberra.

Brady, D. 2004. 'Why public sociology may fail', Social Forces, 82 (4): 1629-38.

Cowen, M. and Shenton, R. 1995. 'The invention of development', in J. Crush (ed.), Power of Development, Routledge, London and New York.

Cowlishaw, G. 2003. 'Euphemism, banality, propaganda: anthropology, public debate and Indigenous communities', Australian Aboriginal Studies, 1: $2-17$.

Cribben, J. 1984. The Killing Times: The Coniston Massacre 1928, Fontana Books, Sydney.

Foucault, M. 1991. 'Governmentality', in G. Burchell, C. Gordon and P. Miller (eds), The Foucault Effect: Studies in Governmentality, Harvester Wheatshaft, London.

Geertz, C. 1988. Works and Lives: the Anthropologist as Author, Stanford University Press, Stanford.

Gordon, C. 1991. 'Governmental rationality: an introduction', in G. Burchell, C. Gordon and P. Miller (eds), The Foucault Effect: Studies in Governmentality, Harvester Wheatshaft, London.

${ }_{17}$ Durkheim, E. Division of Labor in Society, 1984: XXVI, cited in Brady 2004: 1630 
Green, J. with Ti Tree, Mt Allen and Laramba (Napperby) communities. 2003. Central Anmatyerr Picture Dictionary, IAD Press Picture Dictionary Series, IAD Press, Alice Springs.

Holcombe, S. and Sanders, W. 2007a. 'Accommodating difference: the socio-political history of an Aboriginal fringe camp in a small north Australian town', The International Journal of Interdisciplinary Social Science, 2 (2): 339-48.

— and - 2007b. 'Community governance: the Ti Tree Creek Camp study', Working Paper 10, DKCRC, Alice Springs, available at $<$ http://www.desertknowledgecrc.com.au/publications/downloads/ DKCRC-Working-Paper-10-Ti-Tree-Creek-Camp-Study.pdf $>$.

House of Representatives Standing Committee on Aboriginal Affairs (HORSCATAA) 1982. Strategies to Help Overcome the Problems of Aboriginal Town Camps, Report to Parliament of the Commonwealth of Australia, Canberra.

Morton, J. 1994. The Proposed Anmatjere Land Council: Its Historical Antecedents and an Estimation of Levels of Support, Unpublished report to ATSIC, Canberra.

Rose, D. B. 2001. 'The silence and power of women', in P. Brock (ed.), Words and Silences: Aboriginal Women, Politics and Land, Allen \& Unwin, Crows Nest, NSW.

Rose, N. 1999. Powers of Freedom: Reframing Political Thought, Cambridge University Press, Cambridge.

Rowse, T. 1998. White Flour, White Power: From Rations to Citizenship, Cambridge University Press, Cambridge.

Sanders, W. 1984. 'Aboriginal town camping, institutional practices and local politics', in J. Halligan and C. Paris (eds), Australian Urban Politics, Longman Cheshire, Melbourne.

- and Holcombe, S. 2007. 'The Ti Tree Creek Camp study: a contribution to good governance', Ngiya: Talk the Law, 1: 72-92.

Smith, D. 2005. 'Researching Australian Indigenous governance: a methodological and conceptual framework', CAEPR Working Paper No. 29, CAEPR, ANU, Canberra.

Sutton, P. 2001. 'The politics of suffering: Indigenous policy in Australia since the seventies', Revised version of the Inaugural Berndt Foundation Biennial Lecture, Presented to the Australian Anthropological Society Conference, 23 September 2000, UWA, Perth. 
2005. 'Rage, reason and the honourable cause: a reply to Cowlishaw', Australian Aboriginal Studies, 2: 35-43. 